\title{
1: 158364622-158379489
}

National Cancer Institute

\section{Source}

National Cancer Institute. 1:158364622-158379489. NCI Thesaurus. Code C42252.

Physical location of FCGR2B_Gene 